\author{
Alina Walenia \\ Kolegium Nauk Społecznych \\ Uniwersytet Rzeszowski \\ e-mail: alinawalenia@poczta.onet.pl \\ ORCID: 0000-0003-3389-9465
}

\title{
MIEJSCE PUBLICZNEGO DORADZTWA ROLNICZEGO POLSKI W SYSTEMIE WIEDZY I INNOWACJI ROLNICZYCH UNII EUROPEJSKIEJ
}

DOI: $10.15611 /$ pn.2021.3.09

JEL Classification: P3, Q14

(C) 2020 Alina Walenia

Praca opublikowana na licencji Creative Commons Uznanie autorstwa-Na tych samych warunkach 4.0 Międzynarodowe (CC BY-SA 4.0). Skrócona treść licencji na https://creativecommons.org/licenses/by-sa/4.0/deed.pl

Cytuj jako: Walenia, A. (2021). Miejsce publicznego doradztwa rolniczego Polski w Systemie Wiedzy i Innowacji Rolniczych Unii Europejskiej. Prace Naukowe Uniwersytetu Ekonomicznego we Wroctawiu, 65(3).

Streszczenie: System Wiedzy i Innowacji Rolniczych Unii Europejskiej (AKIS) można zdefiniować jako sieć instytutów badawczych, ośrodków doradztwa, szkół rolniczych i pozostałych organizacji pozarządowych zaangażowanych $\mathrm{w}$ pomoc rolnikom w podnoszeniu innowacyjności ich gospodarstw i rozwiązywaniu nowych problemów gospodarczych. W państwach członkowskich UE można zauważyć wiele podobieństw w spójności AKIS. W większości krajów sektor publiczny (na poziomach krajowym, regionalnym i lokalnym) był reprezentowany w AKIS jako dostawca informacji, wsparcia finansowego, a także usług doradczych. W artykule przedstawiono cechy krajowych AKIS w wybranych państwach członkowskich UE (Belgia, Francja, Irlandia, Niemcy, Portugalia). Głównym celem artykułu była ocena publicznego doradztwa rolniczego oferowanego przez wojewódzkie ośrodki doradztwa rolniczego w Polsce w kontekście zasad funkcjonowania systemu AKIS w poszczególnych państwach członkowskich UE.

Słowa kluczowe: doradztwo rolnicze, system wiedzy, innowacje, Unia Europejska.

\section{Wstęp}

Izby rolnicze wraz z jednostkami doradztwa rolniczego tworzą system publicznego doradztwa rolniczego w Polsce. Unia Europejska (UE) nałożyła obowiązek zapewnienia systemu doradztwa rolniczego na kraje członkowskie już w 2007 r., aktual- 
nie sposób jego funkcjonowania określają przepisy rozporządzenia Parlamentu Europejskiego i Rady UE nr 1306/2013 (Rozporządzenie Parlamentu Europejskiego i Rady (UE) nr 1306/2013..., 2013) w sprawie finansowania wspólnej polityki rolnej (WPR), zarządzania nią i jej monitorowania. Stosownie do komunikatu Komisji Parlamentu Europejskiego, Rady Europejskiego Komitetu Ekonomiczno-Społecznego i Komitetu Regionów dotyczącego przyszłości rolnictwa i produkcji żywności doradcom rolniczym została przypisana szczególna rola. W dokumencie tym podkreślono, że jeżeli WPR ma być polityką nieulegającą dezaktualizacji, to zasadnicze znaczenie będzie miało wspieranie wiedzy, innowacji i technologii. Programy, których celem jest m.in. poprawa wyników gospodarczych, społecznych lub dotyczących ochrony środowiska, będą powiązane z usługami doradczymi zapewniającymi wiedzę, porady, umiejętności i innowacje (Wawrzyniak, 2020, s. 137). Zadania dotyczące wdrażania innowacji w sektorze rolnictwa zapewnia System Wiedzy i Innowacji Rolniczych - AKIS (Agricultural Knowledge and Innovation System), który zorganizowany jest w poszczególnych państwach członkowskich na odmiennych zasadach. AKIS w poszczególnych państwach członkowskich UE był istotnie zróżnicowany organizacyjnie: w Rumunii w jego skład wchodziło 500 podmiotów, w Irlandii należało do niego 36 podmiotów, w Bułgarii - 28, w Polsce -3 podmioty (ODR, izby rolnicze, prywatne podmioty), w Szwecji należał do niego jeden podmiot.

Celem niniejszego artykułu jest prezentacja zorganizowanego w poszczególnych państwach członkowskich Systemu Wiedzy i Innowacji Rolniczych. W tekście przedstawiono ocenę publicznego doradztwa rolniczego w Polsce. Opracowanie zrealizowano z wykorzystaniem kilku metod badawczych. Wśród podstawowych wymienić można analizę (porównawczo-opisową) krajowych i międzynarodowych aktów prawnych oraz literatury przedmiotu, a także metodę syntezy i dedukcji. Oceny funkcjonowania systemu doradztwa rolniczego w Polsce w ramach AKIS dokonano na podstawie wyników badań ankietowych ${ }^{1}$ przeprowadzonych w wybranej grupie odbiorców usług doradczych oferowanych przez wybrane jednostki doradztwa rolniczego w Polsce.

${ }^{1}$ Badania ankietowe przeprowadzono w 2019 r. w związku z kontrolą NIK P/19/098. Działalność ośrodków doradztwa rolniczego. Ankiety przeprowadzono w wybranej grupie 100 respondentów korzystających z usług doradztwa rolniczego oferowanych przez wojewódzkie ośrodki doradztwa rolniczego. W grupie tej wyszczególniono 60 rolników prowadzących gospodarstwa rolne o powierzchni do 5 ha, od 5,1 ha do 20 ha, od 20,1 ha do 50 ha i powyżej 50 ha. Badania ankietowe przeprowadzono także w grupie 20 przedsiębiorców działających na obszarach wiejskich i w grupie 20 pozostałych mieszkańców wsi korzystających z usług publicznego doradztwa rolniczego. 


\section{Charakterystyka Systemu Wiedzy i Innowacji Rolniczych w wybranych państwach członkowskich UE}

Pod koniec XX wieku ustanowiono w UE podmiot pod nazwą System Wiedzy i Innowacji Rolniczych (AKIS). Koncepcję tę opracowano na podstawie założeń AKS (Agricultural Knowledge Systems), która powstała w latach 60. ubiegłego wieku. System wprowadzano przez interwencyjną politykę rolną Wspólnoty, która miała na celu koordynację transferu wiedzy i innowacji w celu przyspieszenia restrukturyzacji i modernizacji rolnictwa. Od lat 70. oficjalne organizacje, takie jak OECD i FAO, wprowadziły do dyskursów politycznych koncepcję systemu wiedzy i informacji rolniczej. Od tego czasu nazwa ta ewoluowała, aby ostatecznie przyjąć formę „System Wiedzy i Innowacji Rolniczych" (AKIS).

System Wiedzy i Innowacji Rolniczych można zdefiniować jako sieć instytutów badawczych, ośrodków doradztwa, szkół rolniczych i pozostałych organizacji pozarządowych, zaangażowanych w pomoc rolnikom w podnoszeniu innowacyjności ich gospodarstw i rozwiązywaniu nowych problemów gospodarczych. AKIS opiera się na trzech podstawowych filarach: 1) badaniach (research), 2) kształceniu (education) i 3) upowszechnianiu (extension). W rzeczywistości jest to zbiór jednostek, instytucji i organizacji mających na celu generowanie, przekształcanie, wdrażanie, rozpowszechnianie czy wykorzystanie wiedzy w rolnictwie (Agricultural Knowledge..., 2014). W świadomości społeczności rolniczej funkcjonuje pojęcie systemu doradztwa rolniczego (FAS). FAS opiera się głównie na służbach doradczych, powiązanych instytucjonalnie z różnymi jednostkami organizacyjnymi. Doradztwo świadczy usługi dla rolników, którzy uzyskiwali porady i wsparcie finansowe w ramach kolejnych perspektyw finansowych. Kategoria AKIS nie funkcjonuje w organach państwowych, jednostkach organizacyjnych rolnictwa czy podmiotach badawczych. Pojęcie AKIS nie zostało implementowane do prawodawstwa unijnego, przyjęto natomiast część tych działań w postaci EPI².

System Wiedzy i Innowacji Rolniczych nie ma charakteru sformalizowanego. We wszystkich krajach członkowskich w jego skład wchodzi sieć instytutów naukowych, ośrodków badawczych, szkół rolniczych oraz innych jednostek zaangażowanych w procesy unowocześniania i optymalizowania współczesnej działalności rolniczej. System ulegał stopniowym i ewolucyjnym zmianom odpowiednio do potrzeb środowiska rolniczego. Zmiany te uzależnione były od krajowych rozwiązań prawno-organizacyjnych, możliwości ekonomicznych, społecznych i poziomu zaangażowania podmiotów uczestniczących w działaniach innowacyjnych (Kania, Vinohradnik i Knierim, 2014, s. 6).

System AKIS we Francji tworzą głównie uniwersytety, szkoły inżynieryjne, które kształcą w dziedzinie agronomii, nauk o żywności i środowiska. Ponadto w sektorze rolniczym we Francji działają przede wszystkim publiczne instytuty naukowe,

${ }^{2}$ Europejskie Partnerstwo Innowacyjne. 
a także prywatne. Więź między nauką a praktyką zapewniają stowarzyszenia i izby rolnicze, mające tysiące członków i rozbudowaną sieć placówek terenowych (Labarthe, 2014). System ten jest bardzo podobny do systemu zorganizowanego w Polsce.

W Niemczech, ze względu na występowanie krajów związkowych (16), AKIS ma charakter zdecentralizowany, w związku z czym większość problemów edukacyjnych, badawczych, decyzyjnych i organizacyjnych przekazano krajom związkowym. Najważniejszą rolę odgrywa Agencja ds. Sieci na Obszarach Wiejskich (DVS), która działa jako platforma sieci na poziomie krajowym, a częściowo na poziomie UE. DVS została ustanowiona w celu wspierania współpracy i wymiany między administracją, naukowcami i praktykami w rolnictwie i na obszarach wiejskich. DVS funkcjonuje zatem jako organizacja publiczna posiadająca uprawnienia do przenoszenia i przekształcania wiedzy do szerokiej grupy odbiorców usług AKIS (Paul i in., 2014, s. 13).

Sposób organizacji AKIS w Hiszpanii jest związany z występowaniem 17 wspólnot autonomicznych, które mają dużą swobodę w kształtowaniu struktur organizacyjnych. Główny system badań i innowacji w dziedzinie rolnictwa opiera się na Narodowym Instytucie Badań i Technologii Rolnictwa i Żywności (INIA) będącym krajową instytucją publiczną odpowiedzialną za wymienione funkcje. Ponadto w celu osiągnięcia koordynacji i współpracy między rządem centralnym a samorządami regionalnymi powołano Komitet Koordynacyjny ds. Badań Rolniczych. Funkcję łącznika między nauką a rolnikami pełnią izby rolnicze oraz profesjonalne organizacje rolnicze (OPA) (Esparcia i in., 2014).

W 10 krajach członkowskich budowanie AKIS rozpoczęło się w zasadzie dopiero po ich wstąpieniu do Wspólnoty w 2004 r., przy czym dwa kraje (Bułgaria i Rumunia) weszły do UE trzy lata później (w 2007 r.). W każdym z tych państw system AKIS różnił się pod względem uwarunkowań historycznych, spójności, zarządzania i finansowania. W krajach tych występowały także zróżnicowane powiązania między edukacją, nauką, badaniami i praktyką gospodarczą oraz strukturą organizacyjną państwa. Z tych powodów analiza systemów AKIS w badanych krajach i wyciąganie wniosków nie mogły zostać uogólnione dla całej UE (Sass, 2017, s. 45).

Można zauważyć wiele podobieństw w spójności AKIS. W większości krajów sektor publiczny (na poziomie krajowym, regionalnym i lokalnym) jest reprezentowany w AKIS jako dostawca informacji, wsparcia, a także świadczący usługi doradcze. System AKIS różni się pod względem uwarunkowań historycznych, spójności, zarządzania i finansowania. Prawie we wszystkich państwach istnieją departamenty lub wydziały w ministerstwach rolnictwa odpowiedzialne za sterowanie Systemem Wiedzy i Innowacji Rolniczych. Lokalne czy regionalne agencje rządowe w obszarze rolnictwa funkcjonują we wszystkich państwach członkowskich UE. Najwięcej doradców zatrudnionych jest we Włoszech (879) oraz na Łotwie (125). W skład AKIS wchodzą także inne organizacje doradcze, których najwięcej jest w Bułgarii (291) i Irlandii (110), mających 1000 doradców (Kania i in., 2014, s. 134). 
Sektor badań i edukacji w AKIS reprezentowany jest we wszystkich państwach członkowskich przez uniwersytety dysponujące wydziałami czy instytutami związanymi z rolnictwem. W AKIS sektor prywatny reprezentowany jest przez jednostki przemysłu przetwórczego, niezależnych konsultantów, prywatne firmy doradcze czy grupy należące do rolników. Organizacje pozarządowe w AKIS reprezentowane są przez stowarzyszenia rolnicze, spółdzielnie rolnicze, izby rolnicze, grupy rolników i fundacje. Silnie rozbudowane doradztwo związane z izbami rolniczymi mają Francja (116 izb i 5000 doradców), Austria (9 izb i 600 doradców) oraz Słowenia (jedna izba i 330 doradców). We wszystkich państwach widoczna jest aktywność organizacji pozarządowych działających w sferze rolnictwa.

W zapewnieniu przepływu informacji i transferu innowacji na rzecz rozwoju wsi i rolnictwa ważne jest istnienie efektywnych instytucji doradczych, szkoleniowych i konsultingowych. W ramach AKIS w Polsce istotną rolę w doskonaleniu zawodowym, tzn. uaktualnianiu i podnoszeniu wiedzy rolników i przedsiębiorców wiejskich, odgrywają jednostki doradztwa rolniczego, tj. Centrum Doradztwa Rolniczego oraz wojewódzkie ośrodki doradztwa rolniczego (Wiatrak, 2020, s. 6). Jednostki te biorą aktywny udział w przepływie informacji od instytucji naukowych bezpośrednio do rolnika. Przepływ informacji w doradztwie obrazuje rysunek 1.

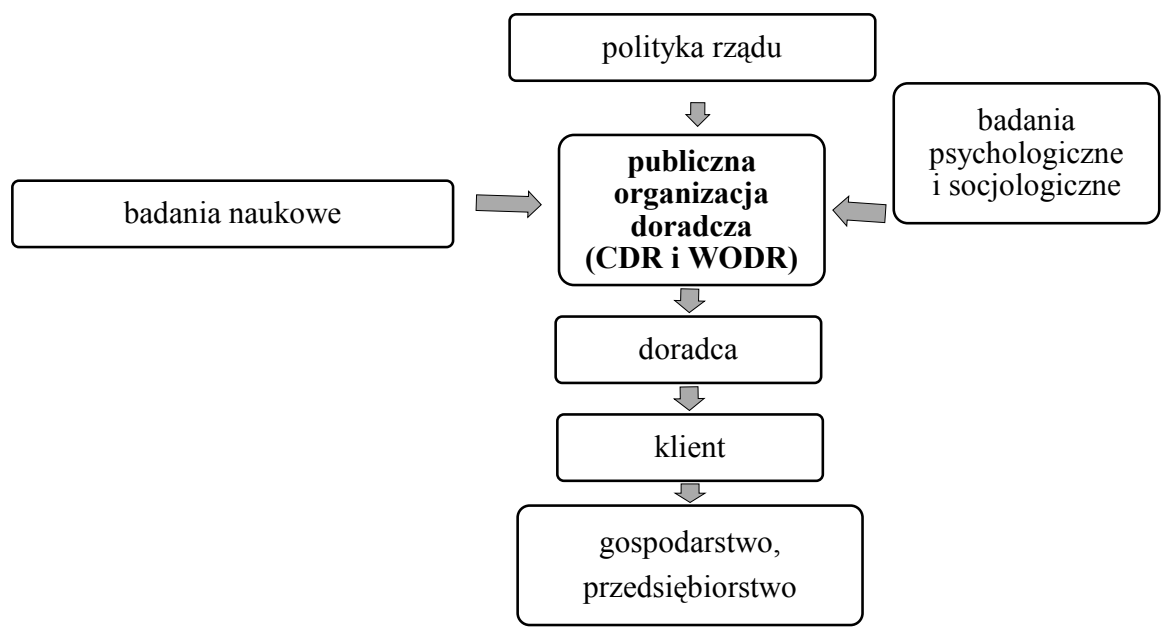

Rys. 1. Przepływ informacji w systemie doradztwa publicznego

Źródło: opracowanie własne.

Doradztwo dotyczy m.in. nowoczesnej uprawy roślin, hodowli zwierząt, informacji o źródłach finansowania innowacji z funduszy UE i ze środków krajowych, transferu technologii (porady prawne), prawa własności intelektualnej (patenty polskie i europejskie, znaki towarowe, tajemnica handlowa, koszty zastosowania metod ochrony), rozwiązań prawnych ułatwiających prowadzenie działalności gospodar- 
czej, a także możliwych źródeł pomocy dla przedsiębiorstw. Można wyodrębnić cztery podstawowe grupy przyczyn korzystania z usług doradczych (Walenia, 2019, s. 5):

- ciągłe zmiany środków produkcji i konieczność mistrzowskiego opanowania technologii ich zastosowania,

- brak pracowników w organizacji mających specjalistyczne kwalifikacje do prowadzenia poważniejszych przedsięwzięć usprawniających,

- napięcie związane z realizacją bieżących zadań, utrudniające skoncentrowanie się pracowników organizacji na przygotowaniu usprawnień,

- brak dystansu (subiektywizm) pracowników organizacji do pojawiających się problemów wymagających rozwiązania w postaci zmiany organizacyjnej.

\section{Ogólna charakterystyka systemu doradztwa w krajach UE}

W krajach UE doradztwo rolnicze nie przyjęło jednorodnych form organizacyjnych, ale występuje jako system powiązanych ze sobą różnych instytucji działających w rolnictwie i jego otoczeniu. Podmioty świadczące usługi doradcze w krajach UE można podzielić na instytucje państwowe i samorządowe, firmy prywatne o charakterze komercyjnym oraz służby doradcze związków rolników, przemysłu rolno-spożywczego i banków finansujących rolnictwo.

System doradztwa rolniczego stanowi jeden z nielicznych elementów funkcjonalnych WPR, który nie przyjął jednakowego charakteru strukturalnego w ramach Wspólnoty. Duża mozaika struktur powoduje, że nie można mówić o ukształtowaniu europejskiego modelu doradztwa rolniczego. Przyczyną tej sytuacji jest fakt, że Komisja Europejska skupiła swoją uwagę na określaniu celów usług doradczych, a nie na określeniu sposobów realizacji zadań. Nie ustalono również funkcji i organizacji jednostek doradczych, liczebności doradców w stosunku do liczby rolników, ich kompetencji, poziomu wykształcenia i doświadczenia. W uregulowaniach prawnych z zakresu doradztwa rolniczego z 2003 r. określono, że działalność doradcza obejmuje co najmniej wymogi podstawowe w zakresie zarządzania oraz zasad dobrej kultury rolnej zgodnej z ochroną środowiska. Te początkowo ogólne cele ulegały stopniowo istotnej zmianie i poszerzeniu w kolejnych perspektywach finansowych. W perspektywie finansowej 2014-2020 określone zostały dodatkowe cele doradztwa rolniczego w zakresie norm dotyczących bezpieczeństwa pracy, opartych na prawodawstwie wspólnotowym oraz usprawnienia zrównoważonego zarządzania gospodarstwami. Katalog usług poszerzono o szkolenia, informowanie i rozpowszechnianie wiedzy, specjalizację rolnictwa czy znajomość nowych technologii informacyjnych (Wawrzyniak, 2019, s. 3).

Klasyfikacji systemów doradztwa rolniczego można dokonywać na wiele różnych sposobów w zależności od przyjętego kryterium podziału. Może nim być np. sposób świadczenia usług, sposób zarządzania, rodzaj świadczonych usług, rodzaj instytucji świadczącej usługi. Jednym z ważniejszych kryteriów jest forma własno- 
ści i sposób finansowania usług doradczych. Analizując poszczególne struktury organizacji doradztwa rolniczego w krajach UE, można wyodrębnić pięć podstawowych systemów doradztwa rolniczego (tab. 1).

Tabela 1. Systemy doradztwa w krajach UE ze względu na formę własności i źródła finansowania po 1 stycznia $2007 \mathrm{r}$.

\begin{tabular}{|l|l|l|l|}
\hline System doradztwa & \multicolumn{1}{|c|}{$\begin{array}{c}\text { Najważniejsze } \\
\text { instytucje }\end{array}$} & Sposób finansowania & Miejsce występowania \\
\hline \multicolumn{3}{|c|}{ Doradztwo publiczne } \\
\hline Państwowy & $\begin{array}{l}\text { doradztwo realizują } \\
\text { organizacje publiczne, } \\
\text { najczęściej na } \\
\text { szczeblach krajowym } \\
\text { i regionalnym }\end{array}$ & $\begin{array}{l}\text { całkowicie finansowane } \\
\text { z budżetu państwa }\end{array}$ & $\begin{array}{l}\text { Austria, Bułgaria, Cypr, } \\
\text { Grecja, Hiszpania, } \\
\text { Rumunia, Słowenia, } \\
\text { Szwecja, Finlandia, } \\
\text { południowe landy } \\
\text { Niemiec, Portugalia }\end{array}$ \\
\hline $\begin{array}{l}\text { Półpaństwowy } \\
\text { (publiczno- } \\
\text { prywatny) }\end{array}$ & $\begin{array}{l}\text { wzrasta rola doradztwa } \\
\text { świadczonego przez } \\
\text { prywatne firmy } \\
\text { konsultingowe }\end{array}$ & $\begin{array}{l}\text { w pełni lub częściowo } \\
\text { za usługi płacą rolnicy, } \\
\text { może mieć charakter } \\
\text { scentralizowany lub } \\
\text { zdecentralizowany }\end{array}$ & $\begin{array}{l}\text { Anglia, Belgia, Czechy, } \\
\text { Litwa, Luksemburg, } \\
\text { Lotwa, Irlandia, Włochy, } \\
\text { Polska, Słowacja, Węgry }\end{array}$ \\
\hline $\begin{array}{l}\text { Doradztwo } \\
\text { autonomiczne } \\
\text { (farmerskie) }\end{array}$ & $\begin{array}{l}\text { doradztwo świadczą } \\
\text { izby rolnicze, } \\
\text { związki farmerów, } \\
\text { stowarzyszenia }\end{array}$ & $\begin{array}{l}\text { środki pochodzące ze } \\
\text { składek członkowskich, } \\
\text { bezpośrednich opłat } \\
\text { rolników }\end{array}$ & $\begin{array}{l}\text { Francja, Dania, północno- } \\
\text {-zachodnie landy Niemiec }\end{array}$ \\
\hline $\begin{array}{l}\text { Komercyjny } \\
\text { komeradztwo świadczą } \\
\text { osoby prywatne }\end{array}$ & $\begin{array}{l}\text { opłaty za usługi } \\
\text { z realizacji projektów, } \\
\text { grantów }\end{array}$ & $\begin{array}{l}\text { Holandia, Estonia, } \\
\text { północno-wschodnie landy } \\
\text { Niemiec }\end{array}$ \\
\hline
\end{tabular}

Źródło: opracowanie własne na podstawie (Wawrzyniak, 2020, s. 14).

Trudno w jednoznaczny sposób określić typy dominujących organizacji doradczych w krajach członkowskich UE 27, ponieważ typy te ewoluują w kierunku coraz większego znaczenia doradztwa prywatnego. Prawie w każdym państwie występuje mieszany, czyli publiczno-prywatny system doradztwa. Większość podmiotów doradztwa publicznego to organizacje tworzone i finansowane przez rządy państw członkowskich. Pozostałe organizacje doradcze są powoływane przez różne instytucje prywatne, jak np. grupy rolników, organizacje samorządowe, organizacje spółdzielcze. 


\section{Ocena publicznych usług doradczych w Polsce - wyniki badań ankietowych}

Z badań ankietowych ${ }^{3}$ wynika, że $\mathrm{w}$ największym zakresie $\mathrm{z}$ usług publicznego doradztwa rolniczego korzystali rolnicy i mieszkańcy obszarów wiejskich $\mathrm{z}$ województw o rozdrobnionej strukturze agrarnej ${ }^{4}$ oraz niewielkim udziale rolnictwa w $\mathrm{PKB}^{5}$, tj. z województw podkarpackiego (78,9\% ankietowanych) i lubelskiego (72,5\% ankietowanych). W najmniejszym zakresie usługi doradcze były przedmiotem zainteresowania odbiorców w województwach, w których dominują duże gospodarstwa rolne, a udział rolnictwa w PKB jest znaczący - $\mathrm{z}$ województw zachodniopomorskiego (43,4\%) i lubuskiego (45,7\%). Zdecydowana większość ankietowanych wskazywała, że korzystała z usług doradztwa rolniczego (rys. 2).

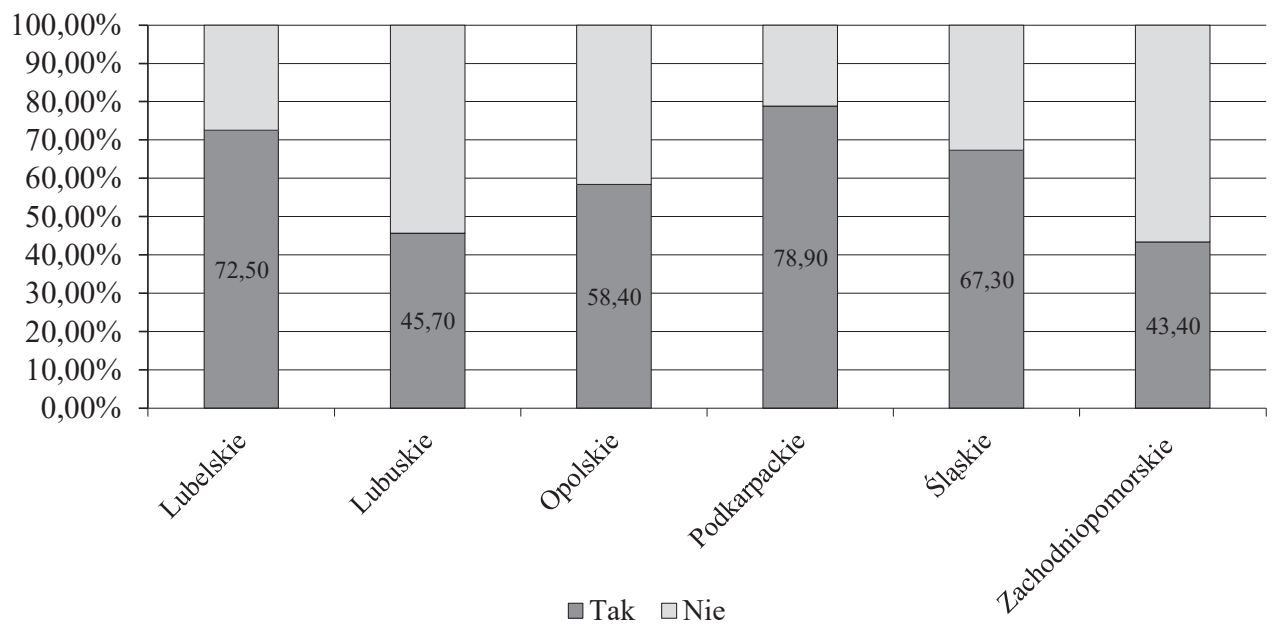

Rys. 2. Ocena korzystania z usług doradczych zarówno odpłatnych, jak i nieodpłatnych (\% wskazań)

Źródło: opracowanie własne na podstawie wyników badań ankietowych.

W poszczególnych województwach rolnicy w różnym stopniu korzystali z usług doradztwa publicznego (rys. 3). Najczęściej, kilka razy w roku, rolnicy korzystali $\mathrm{z}$ usług doradczych $\mathrm{w}$ województwach lubelskim (60\% ankietowanych) i podkar-

${ }^{3}$ Badania ankietowe przeprowadzono w 2019 r. w związku z kontrolą NIK P/19/098. Działalność ośrodków doradztwa rolniczego przeprowadzoną w sześciu wojewódzkich ośrodkach doradztwa rolniczego.

${ }^{4}$ Średnia powierzchnia gospodarstwa w 2019 r. w województwie podkarpackim wynosiła 4, 49 ha, w lubelskim - 8,49 ha, w zachodniopomorskim - 28,7 ha, w lubuskim - 19,03 ha.

${ }^{5}$ Udział rolnictwa w tworzeniu PKB w 2019 r. w województwie podkarpackim wynosił 2,3\%, w lubelskim $-4 \%$, w zachodniopomorskim $-7,4 \%$, w lubuskim $-5,2 \%$. 
packim (58,3\%), sporadycznie - raz na kilka lat - czynili to rolnicy z województw zachodniopomorskiego $(56,3 \%$ ankietowanych), lubuskiego $(44,1 \%)$ i opolskiego $(32,3 \%)$. W grupie respondentów z tych regionów dominowały gospodarstwa rolne o powierzchni powyżej 50 ha.

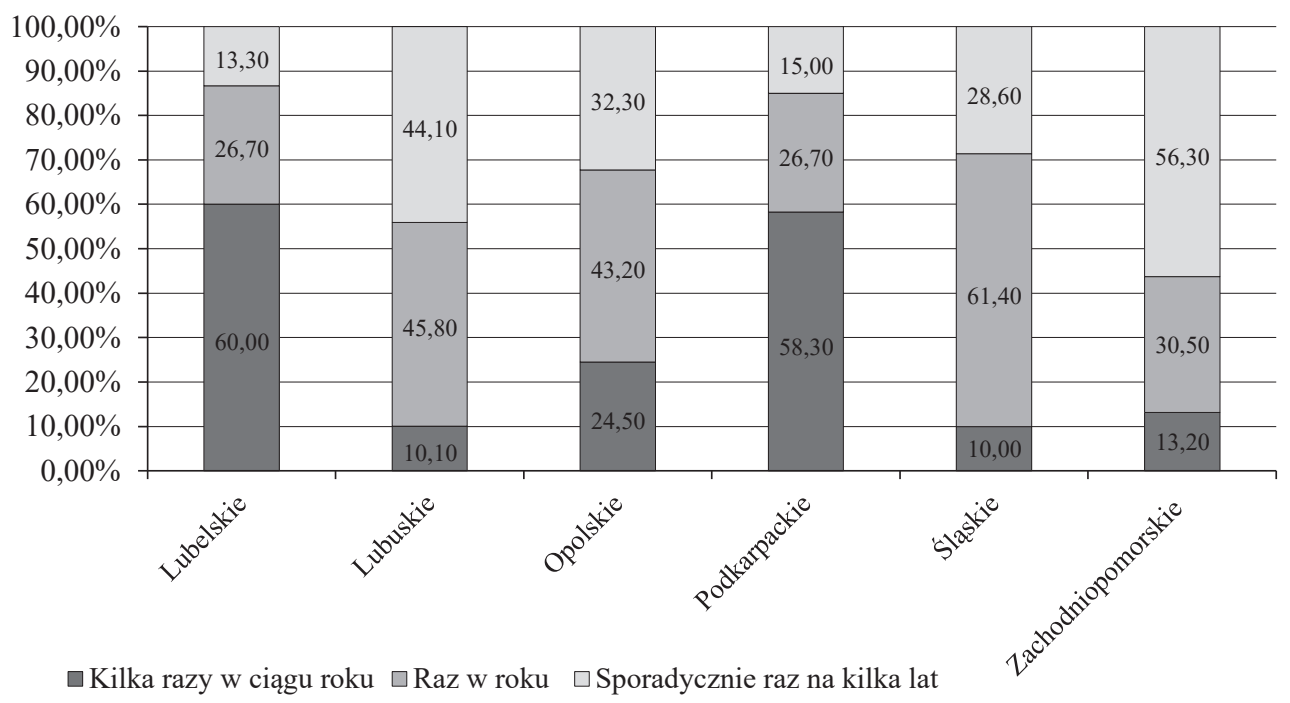

Rys. 3. Częstotliwość korzystania z usług doradczych oferowanych przez publiczne jednostki doradztwa rolniczego (\% wskazań)

Źródło: opracowanie własne na podstawie wyników badań ankietowych.

W grupie rolników, którzy w niewielkim zakresie korzystali z usług doradczych, najczęściej jako przyczynę podawano konkurencyjne usługi specjalistyczne oferowane przez inne podmioty (od 20,2\% wskazań w województwie lubelskim do 45,6\% w podkarpackim). Opinię, że doradztwo publiczne jest mało przydatne, wyraziło od $17,3 \%$ ankietowanych w województwie lubelskim do 32,9\% w opolskim. Badani odpowiadali, że nie znają oferty usług doradczych - tak wskazało od 10,4\% ankietowanych w województwie śląskim do $26,7 \%$ badanych w województwie lubelskim. Znaczna część ankietowanych odpowiadała, że nie potrzebuje usług w zakresie doradztwa oferowanego przez publiczne ośrodki doradztwa (rys. 4).

Ankietowani rolnicy wskazywali na korzystanie w dużym stopniu z usług doradczych oferowanych przez inne prywatne podmioty działające na rynku usług doradczych w poszczególnych województwach (rys. 5). W największym zakresie ankietowani rolnicy korzystali z usług innych podmiotów doradczych w województwach: zachodniopomorskim (72,7\% wskazań), śląskim (63,8\%), opolskim (67\%). W najmniejszym stopniu ankietowani korzystali z usług prywatnego doradztwa w województwach podkarpackim (23,8\% wskazań) i lubelskim (34,6\%). 


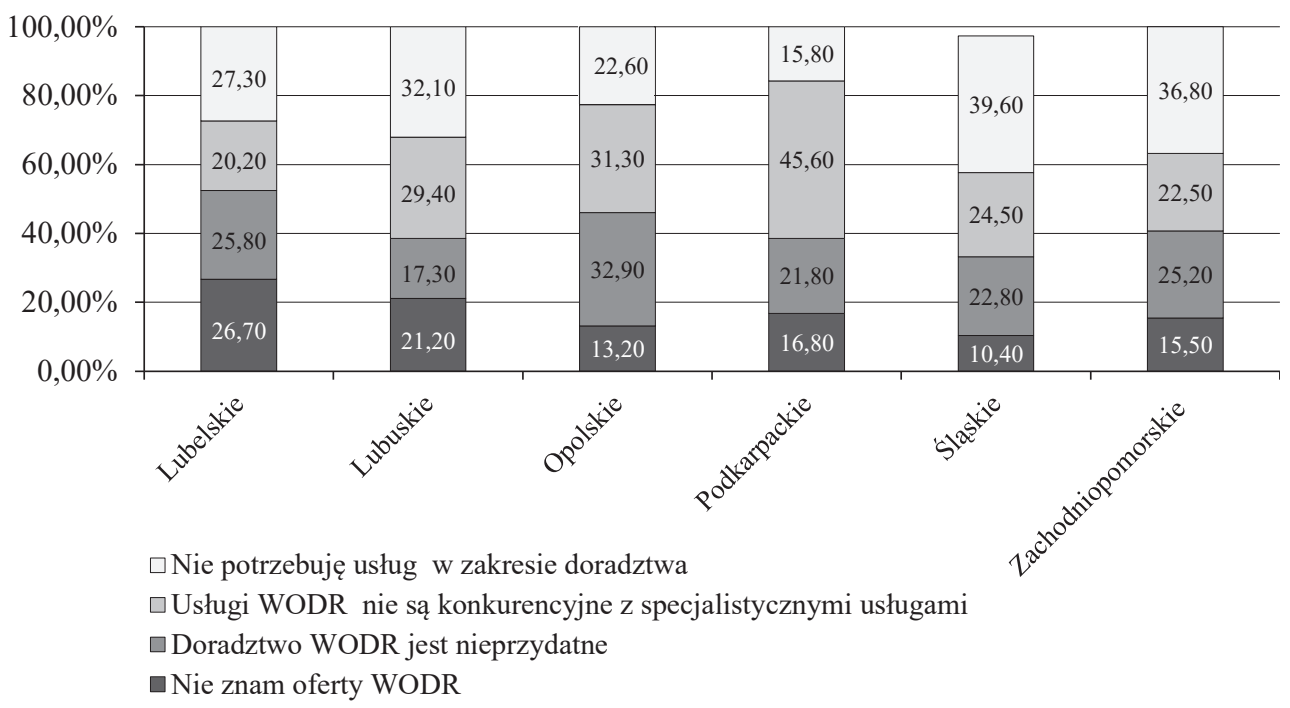

Rys. 4. Przyczyny niekorzystania z usług doradczych przez rolników (\% wskazań)

Źródło: opracowanie własne na podstawie wyników badań ankietowych.

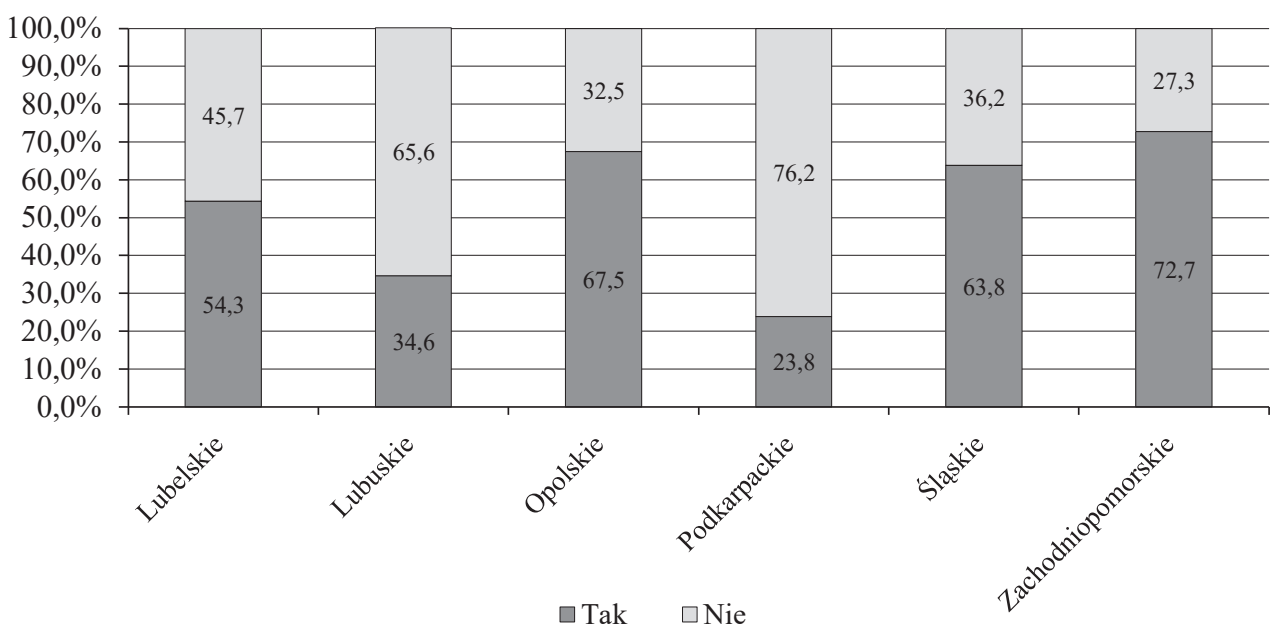

Rys. 5. Korzystanie z pomocy doradczej świadczonej przez inne podmioty niż publiczne działające na rynku usług doradczych - prywatne doradztwo, branżowe (\% wskazań)

Źródło: opracowanie własne na podstawie wyników badań ankietowych.

Wyniki badań ankietowych wskazywały, że usługi podmiotów innych niż publiczne charakteryzowały się kompleksowością i wysoką jakością. Takie opinie wyrażali rolnicy z województw śląskiego $(38,2 \%)$, zachodniopomorskiego $(34,8 \%)$, opolskiego (33,8\%). Ankietowani wskazywali, że jakość usług publicznych nie była 


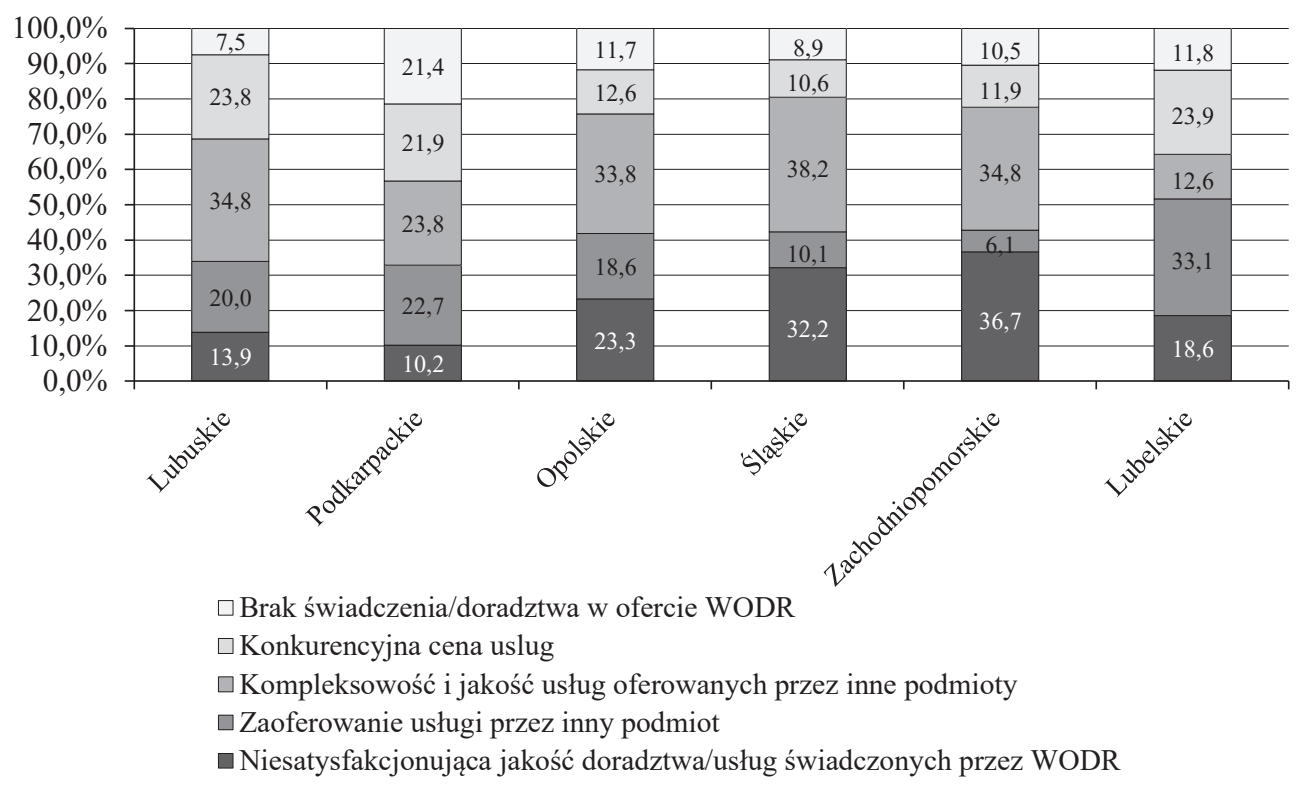

Rys. 6. Przyczyny korzystania z usług doradczych podmiotów innych niż wojewódzkie ośrodki doradztwa rolniczego (\% wskazań)

Źródło: opracowanie własne na podstawie wyników badań ankietowych.

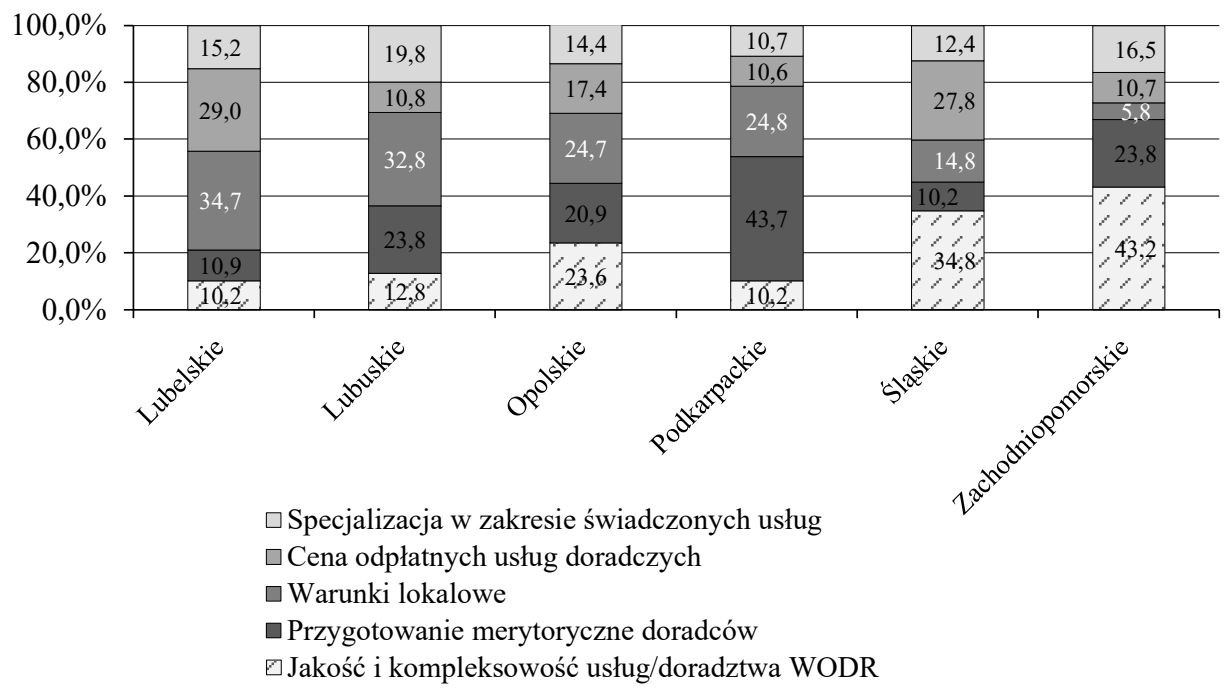

Rys. 7. Opinia rolników o koniecznych zmianach w doradztwie rolniczym świadczonym przez publiczne jednostki doradztwa (\% wskazań)

Źródło: opracowanie własne na podstawie wyników badań ankietowych. 
dla nich satysfakcjonująca oraz że atrakcyjniejsze usługi oferowały podmioty prywatne (rys. 6).

Zdaniem respondentów podstawowe zmiany, jakie powinny mieć miejsce w zakresie doradztwa publicznego w Polsce, to głównie poprawa jakości i kompleksowości usług doradczych powiązana z lepszym przygotowaniem merytorycznym doradców. Znaczna część ankietowanych rolników sygnalizowała nieodpowiednie warunki lokalowe, w których świadczono publiczne usługi doradcze (rys. 7).

Ankietowani rolnicy, dokonując oceny dostosowania systemu publicznego doradztwa rolniczego do potrzeb odbiorców i wyzwań obszarów wiejskich, wskazywali, że w zdecydowanej większości system ten nie był adekwatny do potrzeb odbiorców. Takie odpowiedzi najczęściej podawali rolnicy z województw zachodniopomorskiego, śląskiego i opolskiego. W strukturze agrarnej tych województw dominują gospodarstwa powyżej 20 ha użytków. Ankietowani rolnicy posiadali gospodarstwa rolne powyżej 50 ha użytków rolnych (63\% respondentów w zachodniopomorskim, 67\% w śląskim) z dominującym kierunkiem produkcji roślinnej. Respondenci z województw podkarpackiego i lubelskiego pozytywnie oceniali dostosowanie oferty usług do jej odbiorców. Badani rolnicy prowadzili gospodarstwa rolne o powierzchni od 20 do 50 ha (56\% respondentów z województwa lubelskiego, $20 \%$ z podkarpackiego) z dominującym kierunkiem produkcji zwierzęcej (rys. 8).

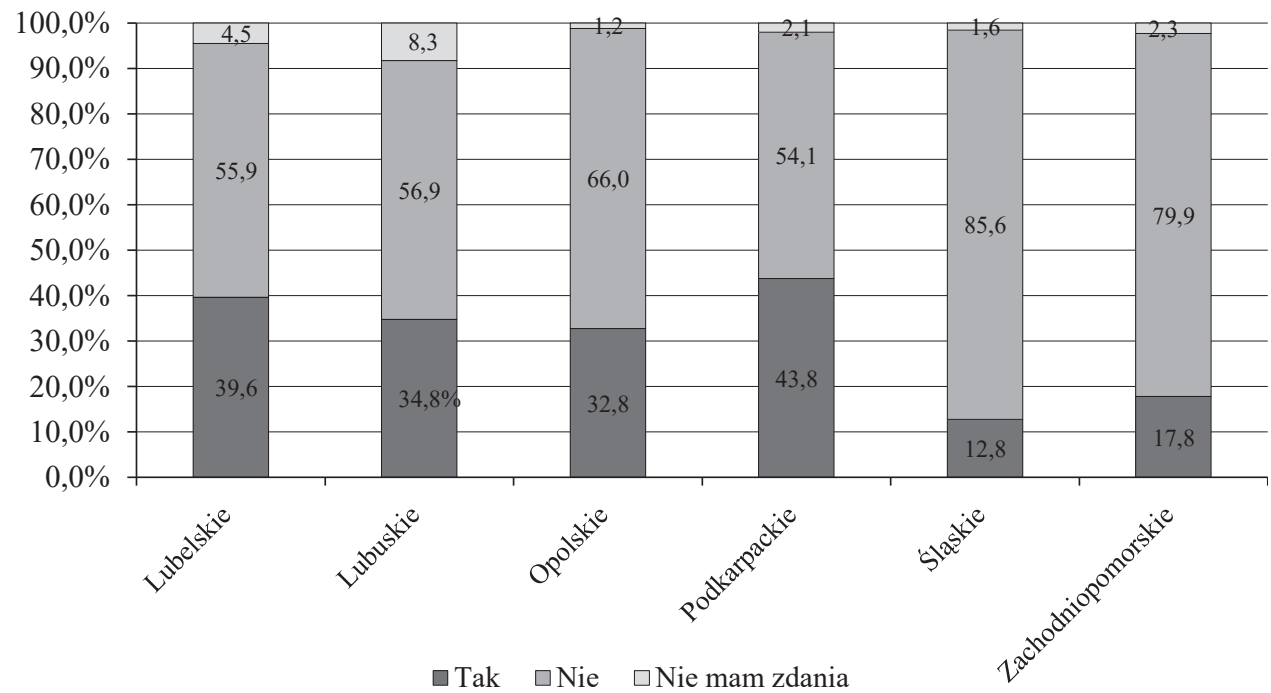

Rys. 8. Ocena dostosowania systemu doradztwa rolniczego do potrzeb odbiorców i wyzwań rozwojowych obszarów wiejskich (\% wskazań)

Źródło: opracowanie własne na podstawie wyników badań ankietowych.

Respondenci odpowiadali, że oferta usług doradczych w największym stopniu uwzględniała głównie potrzeby rolników (rys. 9). Najwyższy odsetek takich wskazań dotyczył województw podkarpackiego (82\%), lubelskiego (68\%), a najniższy - 


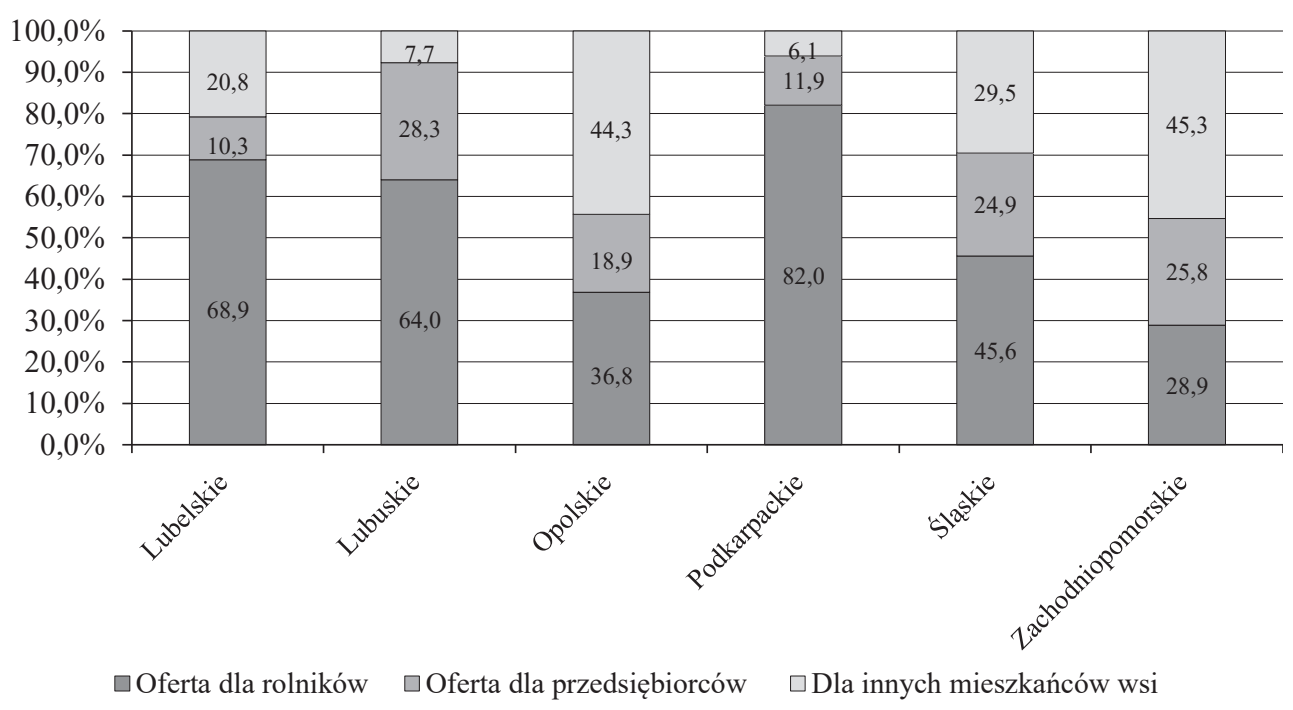

Rys. 9. Ocena stopnia dostosowania oferty publicznego doradztwa do potrzeb rolników, przedsiębiorców i pozostałych mieszkańców wsi (\% wskazań)

Źródło: opracowanie własne na podstawie wyników badań ankietowych.

zachodniopomorskiego (28\%) i opolskiego (36\%). W najmniejszym zakresie oferta usług doradczych dostosowana była do potrzeb przedsiębiorców prowadzących działalność gospodarczą na obszarach wiejskich w województwach lubelskim (10\%) i podkarpackim (12\%). Odpowiedzi respondentów świadczą o tym, że oferta publicznego doradztwa najbardziej uwzględniała potrzeby przedsiębiorców w województwach lubuskim $(28,5 \%)$ i zachodniopomorskim $(25,8 \%)$.

\section{Zakończenie}

Konstatując, należy stwierdzić, że funkcjonujący w Polsce w ramach AKIS system publicznego doradztwa rolniczego powinien być ukierunkowany na kompleksowe publiczne doradztwo organizacyjno-ekonomiczne. Jednostki świadczące usługi doradcze winny współpracować z nauką i oświatą rolniczą. Przejęcie w 2016 r. nadzoru nad jednostkami doradztwa rolniczego przez ministra rolnictwa i rozwoju wsi zapewniło utrzymanie jednolitych standardów świadczenia usług doradczych, a tym samym dostosowanie ich do potrzeb rolników, przedsiębiorców będących ich odbiorcami. Wyniki badań wskazują na wzrastającą rolę prywatnego doradztwa rolniczego w Polsce. W opinii beneficjentów usług doradczych główną tego przyczyną jest możliwość korzystania z usług innych podmiotów, które charakteryzują się kompleksowością i wysoką jakością. Dotyczyło to w szczególności województw śląskiego (38,2 \%), zachodniopomorskiego $(34,8 \%)$ i opolskiego $(33,8 \%)$. Zdaniem większości respondentów oferta publicznego doradztwa rolniczego jest skierowana 
głównie do rolników prowadzących działalność w małych i średnich gospodarstwach rolnych. Badania dowiodły, że podstawowe zmiany w zakresie doradztwa publicznego w Polsce powinny dotyczyć przede wszystkim poprawy jakości i kompleksowości usług doradczych, a także że jednostki doradztwa rolniczego nie podejmowały działań w celu określenia najbardziej odpowiednich usług dostosowanych do specyfiki rolnictwa $\mathrm{w}$ danym regionie. Zakres zadań doradczych nie był w pełni dostosowany do zmieniających się uwarunkowań w rolnictwie, jego specyfiki oraz związanych z tym oczekiwań beneficjentów.

Usługi doradcze powinny łączyć praktyki rolnicze i zarządzanie gospodarstwem z normami dotyczącymi ochrony środowiska, zmian klimatu, zasad dobrej kultury rolnej, bezpieczeństwa żywności, zdrowia i dobrostanu zwierząt. Obszary te powinny stanowić kompleksowy system doradztwa rolniczego powiązanego z systemem doradztwa rolniczego UE.

Rezultaty badań potwierdziły, że oferta usług doradczych publicznego doradztwa rolniczego, aby mogła skutecznie konkurować z prywatnymi podmiotami doradczymi, musi być zmieniona. Powinny być w niej wyszczególnione działania skierowane do konkretnych grup odbiorców usług doradczych i powinny uwzględniać ich zróżnicowanie i wynikające stąd oczekiwania.

\section{Literatura}

Agricultural Knowledge and Innovation Systems in Transition - a reflection paper. (2012). Brussels: Standing Committee on Agricultural Research (SCAR), Working Group AKIS.

Agricultural Knowledge and Innovation Systems towards 2020 - an orientation paper on linking innovation and research. (2014). Brussels.

Agricultural Knowledge and Innovation Systems towards the future - a foresight paper. (2016). Brussels: Standing Committee on Agricultural Research (SCAR), Strategic Working Group AKIS.

Council Regulation (EC) No 1782/2003 of 29 September 2003 establishing common rules for direct support schemes under the common agricultural policy and establishing certain support schemes for farmers EC) No 1782/2003 of 29 September 2003 establishing common rules for direct support schemes under the common agricultural policy and establishing certain support schemes for farmers.

Esparcia, J. i in. (2014). AKIS and advisory services in Spain report for the AKIS inventory (WP3) of the PRO AKIS Project. Universitat Valencia.

Kania, J., Vinohradnik, K. i Knierim, A. (2014). WP3 - AKIS in the EU: The inventory final report (volume I and II, Summary findings). Kraków: PROAKIS.

Komunikat Komisji Parlamentu Europejskiego, Rady Europejskiego Komitetu Ekonomiczno-Społecznego i Komitetu Regionów z dnia 29 listopada 2017 r. w sprawie finansowania wspólnej polityki rolnej, zarządzania nią i jej monitorowania

Labarthe, P. (2014). AKIS and advisory services in Country (Report for the AKIS inventory (WP3) of the PRO AKIS Project). Brussels.

Nosecka, B. (2018). Wsparcie innowacyjności w polskim rolnictwie. Roczniki Naukowe Stowarzyszenia Ekonomistów Rolnictwa i Agrobiznesu, 20(4).

Paul, C. i in. (2014). AKIS and advisory services in Germany (Report for the AKIS inventory (WP3) of the PRO AKIS Project). Brussels. 
Rozporządzenie Parlamentu Europejskiego i Rady (UE) nr1306/2013 z dnia 17 grudnia 2013 r. w sprawie finansowania wspólnej polityki rolnej, zarządzania nią i monitorowania jej oraz uchylające rozporządzenie Rady (EWG) nr 352/78, (WE) nr 165/94, (WE) nr 2799/98, (WE) nr 814/2000, (WE) nr 1290/2005 i (WE) nr 485/2008 (Dz. Urz. UE L 347 z 20 grudnia 2013 r., s. 549, ze zm.)

Rydin, Y. i Falleth, E. (2006). Networks and institutions in natural resource management. Cheltenham, UK, Northampton MA, USA: Edward Elgar Publishing.

Sass, R. (2017). Doradztwo rolnicze - doświadczenia transformacji i nowe wyzwania. Roczniki Naukowe Stowarzyszenia Ekonomistów Rolnictwa i Agrobiznesu, XIX(2).

Stimson, R., Stough, R. R. i Salazar, M. (2009). Leadership and institutions in regional endogenous development. New horizons in regional science. Cheltenham, UK Northampton, MA, USA: Edward Elgar.

Walenia, A. (2019). Zmiany w administracji rolnej i ich wpływ na wdrażanie instrumentów wsparcia rolnictwa w Polsce. Prace Naukowe Uniwersytetu Ekonomicznego we Wrocławiu, 63(11).

Wiatrak, A. P. (2020). Wiedza w systemie doradztwa rolniczego. Zagadnienia Doradztwa Rolniczego, (3).

Wawrzyniak, B. M. (2019). Przegląd Systemów Doradztwa Rolniczego (FAS) i Systemów Wiedzy i Innowacji Rolniczych (AKIS) w krajach członkowskich UE. Zagadnienia Doradztwa Rolniczego, 2(96), 34-48.

Wawrzyniak, B. M. (2020). Instrumenty wsparcia Wspólnej Polityki Rolnej w perspektywie finansowej 2021-2027. Centrum Doradztwa Rolniczego w Brwinowie, Oddział w Poznaniu.

\title{
THE PLACE OF PUBLIC AGRICULTURAL CONSULTANCY IN POLAND WITHIN THE EU AGRICULTURAL KNOWLEDGE AND INNOVATION SYSTEM
}

\begin{abstract}
The Agricultural Knowledge and Innovation System (AKIS) may be defined as a network of research institutes, consultancy centres, agricultural schools and other non-governmental organisations involved in helping farmers with improving the innovation of their farms and solving new economic problems. One can notice many similarities in the cohesion of the AKIS system in individual EU member states. In the majority of countries, the public sector (at national, regional and local level) was represented in AKIS as the provider of information, financial support, and consultancy services. The article presents the features of national AKIS in selected EU countries (Belgium, France, Ireland, Germany, Portugal). The purpose of the article included the assessment of the public agricultural consultancy offered by voivodeship centres of agricultural consultancy in Poland in the context of the rules of functioning of the AKIS system in individual EU member states.
\end{abstract}

Keywords: agricultural consultancy, Agricultural Knowledge and Innovation System, European Union. 